\title{
SISTEM INFORMASI PRESENSI FINGERPRINT DIKTENDIK BERBASIS WEB (STUDI KASUS : MA AR-ROSYIDIYAH BENGKALIS)
}

\author{
Ratna Wulandari $^{1}$, Anita Febriani ${ }^{2}$, Uci Rahmalisa ${ }^{3}$ \\ ${ }^{1,3}$ Sistem Informasi, STMIK Hang Tuah Pekanbaru \\ ${ }^{2}$ Teknik Informatika, STMIK Hang Tuah Pekanbaru \\ Iratnawulandari2109@gmail, ${ }^{2}$ nitasuheri@gmail.com, ${ }^{3}$ ucirahmalisa89@gmail.com
}

\begin{abstract}
Abstrak
Madrasah Aliyah Ar-Rosyidiyah Bengkalis menerapkan presensi pendidik dan tenaga kependidikan dengan cara manual dimana setiap pendidik dan tenaga kependidikan menandatangani sebuah lembar absen untuk presensi, kemudian lembar absen tersebut diolah kembali kedalam laporan bulanan. Presensi secara manual juga membuat tenaga kependidikan dalam hal ini staf tata usaha masih sulit mencari data presensi yang dibutuhkan. Dari sisi keamanan, sistem presensi manual masih sangat rawan terhadap kecurangan data, rusak atau hiangnya berkas yang dapat menyebabkan terlambatnya arus informasi presensi dalam proses merekap data, dan menjadi kurang efektif bagi suatu lembaga sekolah. Berdasarkan hal tersebut, maka dibutuhkan sebuah sistem yang terintergrasi dengan fingerprint yang dapat menerima data dari fingerprint dan dilengkapi dengan pencatatan, pengolahan dan rekapitulasi data. Penelitian ini akan menghasilkan sistem presensi diktendik berbasis web yang terintegrasi dengan finger print, yang dilengkapi dengan pencatatan, pengolahan dan rekapitulasi data presensi dalam bentuk tabel dan grafik. Sistem informasi presensi fingerprint diktendik berbasis web, mampu mengubah kegiatan presensi yang menggunakan cara manual menjadi menggunakan sistem yang terintegrasi dengan fingerprint, mempermudah staf tata usaha dalam hal mencari dan mengolah data presensi, serta mampu meningkatkan keamanan presensi.
\end{abstract}

Kata kunci : Fingerprint, Presensi, Web, Rekapitulasi

\section{Pendahuluan}

Teknologi Informasi sangat berperan penting dalam memperbaiki kualitas suatu lembaga atau perusahaan. Penggunaannya tidak hanya sebagai proses otomatisasi terhadap akses informasi, tetapi juga menciptakan akurasi, kecepatan, dan kelengkapan sebuah sistem yang terintegrasi, sehingga proses organisasi yang terjadi akan efisien, terukur, dan fleksibel. Bagi lembaga pendidikan pemanfaatan teknologi informasi dibutukan untuk meningkatkan mutu dari lembaga pendidikan tersebut, sehingga terselenggaranya pendidikan yang berkualitas unggul.

Salah satu faktor penting penunjang terselenggaranya pendidikan adalah pendidik dan tenaga kependidikan, untuk itu kinerja pendidik dan tenaga kependidikan harus senantiasa memiliki kinerja yang baik dan diperhatikan. Salah satunya adalah dari aspek kedisiplinan dan kehadiran tepat waktu yang dapat dilihat dari presensi.

Madrasah Aliyah (MA) Ar-rosyidiyah Bengkalis adalah salah satu lembaga sekolah swasta di kabupaten Bengkalis dengan jumlah pendidik 26 orang dan tenaga kependidikan sebanyak 4 orang. Sebagai penyelenggara pendidikan yang di kelola oleh non pemerintah, lembaga sekolah harus berkompetisi dengan penyelenggara pendidikan lainnya yang ada di kabupaten Bengkalis.
Berdasarkan informasi yang didapat, penerapan presensi pendidik dan tenaga kependidikan di MA ArRosyidiyah dilakukan dengan cara manual dimana setiap pendidik dan tenaga kependidikan menandatangani sebuah lembar absen untuk presensi pada pukul 7 pagi dan pukul 2 siang, kemudian lembar absen tersebut diolah kembali kedalam laporan bulanan.

Pengolahan presensi secara manual menimbulkan resiko kecurangan data pada saat proses presensi berlangsung, misalnya digantikan atau dititipkan oleh orang lain sehingga data presensi menjadi tidak valid dan menghilangkan sanksi yaitu Surat Peringatan (SP) yang harus diterima bagi pendidik dan tenaga kependidikan apabila tidak hadir sebanyak 3 kali berturut turut tanpa keterangan.

Presensi secara manual juga membuat tenaga kependidikan dalam hal ini staf tata usaha masih sulit mencari data presensi yang dibutuhkan. Dari sisi keamanan, sistem presensi manual masih sangat rawan, apabila berkas rusak atau hilang bisa menyebabkan terlambatnya arus informasi presensi pendidik dan tenaga kependidikan dalam proses merekap data, sehingga menjadi kurang efektif bagi suatu lembaga sekolah.

Berdasarkan masalah di atas, maka penulis tertarik untuk mengangkat skripsi yang berjudul "Sistem Informasi Presensi Fingerprint DIKTENDIK 
Berbasis Web (Studi Kasus: MA Ar-Rosyidiyah Bengkalis)".

\section{Tinjauan Pustaka}

\subsection{Kajian Terdahulu}

Penelitian yang terkait tentang pembangunan sistem informasi presensi yaitu penelitian web service for student attendance management system. Penelitian ini bertujuan untuk mengembangkan sistem manajemen informasi kehadiran mahasiswa untuk mengelola informasi kehadiran mahasiswa di setiap akedemi dan institute berbasis webservice (Pai dkk, 2016).

Septiawan, dkk (2016) di dalam penelitiannya perancangan dan implementasi presensi digital guru dan karyawan SMA Negeri 9 Semarang. Penelitian ini menghasilkan sistem presensi berbasis web yang memiliki keunggulan dalam pengolahan data dan penyaijan informasi yang lebih cepat.

Efendi (2014) di dalam penelitiannya sistem presensi online berbasis web service dengan integrasi antara sistem sidik jari dan login e-learning. Penelitian ini menghasilkan presensi secara online dari data log fingerprint dan data login e-learning serta dapat menghasilkan laporan presensi. Penelitian ini menggunakan model pengembangan incremental yang merupukan perbaikan dari model waterfall.

Dewi, dkk (2014) di dalam penelitiannya aplikasi rekapitulasi elektronik absensi guru dan pegawai (Area - GP) pada sekolah menengah atas. Penelitian ini menghasilkan aplikasi rekapitulasi absensi guru dan pegawai secara elektronik yang dapat menyajikan informasi kinerja guru dan pegawai dengan tepat dan akurat.

Wibowo dan Santi (2012) didalam penelitian nya rekayasa database sekolah guna membangun presensi online berbasis bidik jari dan terintegerasi dengan perangkat pencetak idcard. Penelitian ini membangun sebuah sistem informasi yang dapat membuat database personal sekolah yang terdiri dari siswa, guru, dan karyawan tata usaha yang dapat menghitung (merekapitulasi) presensi kehadiran setiap saat yang terintegrasi dengan perangkat yang dapat mencetak kartu identitas sekolah, yang biasanya kartu identitas ini dimiliki oleh setiap siswa, guru, dan karyawan sekolah.

Armana (2012) di dalam penelitiannya perancangan dan implementasi untuk transfer data pada modul Harisma (Human Resource Management System). Penelitian ini menghasilkan sistem kepegawaian dan penggajian pegawai. Sistem Harisma terintegerasi dengan alat absensi dengan kartu barcode, finger print dan lain sebagainya.

Adapun penelitian di atas yang mendekati dengan penelitian penulis yaitu Armana (2012), septiawan (2016) yang menghasilkan sistem presensi berbasis web, dan Efendi (2014) yang menghasilakn presensi secara online dari data log fingerprint dan data login elearning serta dapat menghasilkan laporan presensi.
Perbedaan penelitian penulis dengan penelitian diatas ialah penelitian penulis hanya menghasilkan sistem presensi berbasis web yang mengambil data log fingerprint, dan tidak menggunakan e-learning. Sedangkan persamaan nya ialah penelitian diatas dan penulis sama-sama menggunakan bahasa pemrograman PHP dan database MySQL.

\subsection{Landasan Teori}

\section{1) Presensi}

Presensi karyawan adalah suatu kegiatan pencatatan terhadap setiap kehadiran karyawan dengan tujuan untuk mengetahui data yang berkaitan dengan kehadiran karyawan secara periodik baik harian maupun bulanan (Rozikin dan Purwantini, 2014).

Presensi adalah pencatatan dan pengolahan data presensi yang dilakukan secara terus-menerus. Pencatatan dilakukan setiap hari kerja dan dilakukan pelaporan. Presensi pegawai merupakan salah satu tolak ukur metode pengembangan pegawai. Jika absensi pegawai setelah mengikuti pengembangan menurun, maka metode pengembangan yang dilakukan baik, sebaliknya jika absensi pegawai tetap berarti metode pengembangan yang diterapkan kurang baik. (Dewi dkk, 2015).

\section{2) Fingerprint}

Sidik jari adalah gurat-gurat yang terdapat di kulit ujung jari. Sistem pengamanan dengan menggunakan sidik jari sudah mulai digunakan di Amerika oleh E. Henry pada tahun 1901. Sistem Henry menggunakan pola ridge (terdapat pada punggung alur kulit tangan dan kaki), yang terpusat pola jari tangan, jari kaki, khususnya telunjuk.

Para pakar membuktikan bahwa tidak ada dua individu yang mempunyai pola ridge yang serupa. Pola ridge tidak bisa diwariskan. Pola ridge dibentuk waktu embrio, dan tidak pernah berubah seumur hidup. Perubahan pada pola ridge hanya dapat terjadi akibat trauma, misal akibat luka-luka, terbakar, penyakit, atau penyebab lain.

Untuk mengidentifikasi suatu pola sidik jari, dapat dilihat pada bagian delta. Bagian delta adalah sebuah titik temu dimana ridge dari 3 buah arah akan bertemu. Pada umumnya pola sidik jari dapat langsung dibedakan jika kita melihat bagian tengah jari dan bagian delta. Akan tetapi, tidak demikian halnya dengan bagian tepi jari. Pola pada bagian tepi jari susah dibedakan satu sama lain karena hampir semua sidik jari mempunyai aliran ridge yang sama di batas sidik jari.

Mesin pemindai sidik jari akan mencari titiktitik ini dan membuat pola dengan menghubungkan titik-titik tersebut. Pola yang didapat dari menghubungkan titik-titik inilah yang nantinya akan digunakan untuk melakukan pencocokan bila ada jari yang dipindai. Jadi, sebenarnya mesin sidik jari tidak mencocokkan gambar, tapi mencocokkan pola yang didapat dari minutiae-minutiae ini. Scanning sidik jari dilakukan dengan alat elektronik (dalam hal ini mesin 
absensi sidik jari). Hasil scanning lalu disimpan dalam format digital pada saat registrasi atau enrollment atau pendaftaran sidik jari. Setelah itu, rekaman sidik jari tersebut diproses dan dibuatkan daftar pola fitur sidik jari yang unik. Pola fitur sidik jari yang unik tersebut kemudian disimpan dalam memori atau database. Pada saat identifikasi, pola minutiae tersebut kemudian dicocokkan dengan hasil scan sidik jari. (Dewi, dkk 2015)

3) Pendidik dan Tenaga Kependidikan

Menurut Undang-Undang Republik Indonesia Nomor 20 Tahun 2003 Tentang Sistem Pendidikan Nasional Bab 1 Pasal 1: Pendidik adalah tenaga kependidikan yang berkualifikasi sebagai guru, dosen, konselor, pamong belajar, widyaiswara, tutor, instruktur, fasilitator, dan sebutan lain yang sesuai dengan kekhususannya, serta berpartisipasi dalam menyelenggarakan pendidikan.

Tenaga kependidikan adalah anggota masyarakat yang mengabdikan diri dan diangkat untuk menunjang penyelenggaraan pendidikan.

\section{4) Rekapitulasi}

Pengertian rekapitulasi menurut Kamus Besar Bahasa Indonesia (KBBI) adalah 1. Ringkasan, ikhtisar; 2. Ringkasan isi atau ikhtisar pada akhir laporan atau akhir hitungan; 3. Pembuatan rincian data yang bercampur aduk menurut kelompok utama.

5) Aplikasi

Terdapat dua kelompok pendekatan di dalam pendefenisian sistem, yaitu kelompok yang menekankan pada prosedur dan kelompok yang menekankan pada elemen atau komponennya. Pendekatan yang menekankan pada prosedur mendefenisikan sistem sebagai suatu jaringan kerja banyak prosedur yang saling berhubungan, berkumpul bersama-sama untuk melakukan suatu kegiatan atau untuk menyelesaikan suatu sasaran tertentu. Sedangkan pendekatan sistem yang lebih menekankan pada elemen atau komponen mendefenisikan sistem sebagai kumpulan elemen yang berinteraksi untuk mencapai suatu tujuan tertentu. Kedua kelompok defenisi ini adalah benar dan tidak bertentangan, yang berbeda adalah cara pendekatannya (Sutabri, 2012: 2).

Sistem adalah sekumpulan elemen yang saling terkait atau terpadu yang dimaksudkan untuk mencapai suatu tujuan. Sebagai gambaran, jika dalam sebuah sistem terdapat elemen yang tidak memberikan manfaat dalam mencapai tujuan yang sama, maka elemen tersebut dapat dipastikan bukanlah bagian dari sistem (Kadir, 2014: 61).

6) Informasi

Bagi suatu sistem, informasi memegang peranan yang sangat penting. Suatu sistem yang kurang mendapatkan informasi akan menjadi luruh, kerdil dan akhirnya berakhir. Informasi berkaitan berkaitan erat dengan data dan harus dibedakan antara keduanya.

Data adalah deskripsi tentang benda, kejadian, aktivitas, dan transaksi, yang tidak mempunyai makna atau tidak mempunyai pengaruh secara langsung kepada pemakai. Data dapat berupa nilai yang terformat, text, citra, audio, dan video (Kadir, 2014: 44).

Informasi adalah data yang telah diklasifikasikan atau diolah atau diinterpretasikan untuk digunakan dalam proses pengambilan keputusan. Sistem pengolahan informasi akan mengolah data menjadi informasi atau mengolah data dari bentuk tak berguna menjadi berguna bagi penerimanya (Sutabri, 2012: 22).

7) Sistem Informasi

Sistem informasi adalah suatu sistem di dalam suatu organisasi yang mempertemukan kebutuhan pengolahan transaksi harian yang mendukung fungsi operasi organisasi yang bersifat manajerial dengan kegiatan strategi dari suatu organisasi untuk dapat menyediakan laporan-laporan yang diperlukan oleh pihak luar tertentu (Sutabri, 2012: 38).

8) Metode PIECES

PIECES Framework adalah kerangka yang dipakai untuk mengklasifikasi-kan suatu problem, opportunities, dan directives yang terdapat pada bagian scope definition analisa dan perancangan sistem. Dengan kerangka ini, dapat dihasilkan hal-hal baru yang dapat menjadi pertimbangan dalam pengembangan sistem. Metoda PIECES yang terdiri dari Performance, Information/data, Control/security, Efficiency, (Tulah dan Hanafi, 2014)

9) $U M L$

Unified modeling language (UML) muncul karena adanya kebutuhan pemodelan visual untuk menspesifikasikan, menggambarkan, membangun, dan dokumentasi dari perangkat lunak. UML merupakan bahasa visual untuk pemodelan dan komunikasi mengenai sebuah sistem dengan menggunakan diagram dan teks-teks pendukung (Rosa \&Shalahuddin, 2013: 137).

\section{0) PhpMyAdmin}

PHPMyAdmin adalah perangkat lunak yang bebas ditulis dalam bahasa pemrograman PHP yang digunakan untuk menangani administrasi MySQL melalui jejaring jagat jembar (World Wide Web). PHPMyAdmin mendukung berbagai operasi MySQL, diantaranya (mengolah basis data, table - table, bidang (fields), relasi (relation), indeks, pengguna (users), perjanjian (permission) dan lain-lain) (Rozaq $\mathrm{dkk}, 2015)$

11) $\mathrm{PHP}$

PHP adalah bahasa pemrograman yang digunakan secara luas untuk penanganan pembuatan dan pengembangan sebuah web dan biasa digunakan pada HTML. PHP merupakan singkatan dari "PHP: Hypertext Preprocessor", dan merupakan bahasa yang disertakan dalam dokumen HTML, sekaligus bekerja di sisi server (server-side HTML-embedded scripting). Artinya sintaks dan perintah yang diberikan akan sepenuhnya dijalankan di server tetapi disertakan pada halaman HTML biasa, sehingga script-nya tak Nampak disisi client. 
PHP dirancangan untuk dapat bekerja sama dengan database server dan dibuat sedemikian rupa sehingga pembuatan dokumen HTML yang dapat mengakses database menjadi bagitu mudah. Tujuan dari bahasa scripting ini adalah untuk membuat aplikasi dimana aplikasi tersebut yang dibangun oleh PHP pada umumnya akan memberikan hasil pada web browser, tetapi prosesnya secara keseluruhan di jalankan di server (Palit dkk, 2015).

\section{2) $H T M L$}

HTML (Hypertext Markup Language) merupakan suatu script yang bisa menampilkan informasi dan daya kreasi kita melalui internet. HTML sendiri adalah suatu dokumen teks biasa yang mudah untuk dimengerti dibandingkan bahasa pemrograman lainnya, dan karena bentuknya itu maka HTML dapat dibaca oleh platform yang berlainan seperti windows, UNIX dan lainnya. (Wardani, 2013).

\section{3) $W E B$}

World Wide Web atau sering dikenal sebagai web adalah suatu layanan sajian informasi yang menggunakan konsep hyperlink (tautan), yang memudahkan surfer (sebutan para pemakai komputer yang melakukan browsing atau penelusuran informasi melalui internet). Keistimewaan inilah yang telah menjadikan web sebagai service yang paling cepat pertumbuhannya. Web mengijinkan pemberian highlight (penyorotan atau penggaris bawahan) pada kata kata atau gambar dalam sebuah dokumen untuk menghubungkan atau merujuk ke media lain seperti dokumen, frase, movie clip atau file suara. Web dapat menghubungkan dari sembarangan tempat dalam sebuah dokumen atau gambar ke sembarang tempat di dokumen lain. Dengan sebuah browser yang memiliki Graphical User Interface (GUI), link link dapat di hubungkan ke tujuannya dengan menunjuk link tersebut dengan mouse dan menekannya (Palit dkk, 2015).

\section{Metode Penelitian}

Metode yang penulis gunakan adalah metode waterfall. Secara garis besar metode waterfall mempunyai langkah-langkah sebagai berikut: Analisa, Desain, Penulisan, Pengujian dan Penerapan serta Pemeliharaan. (Kadir, 2003).

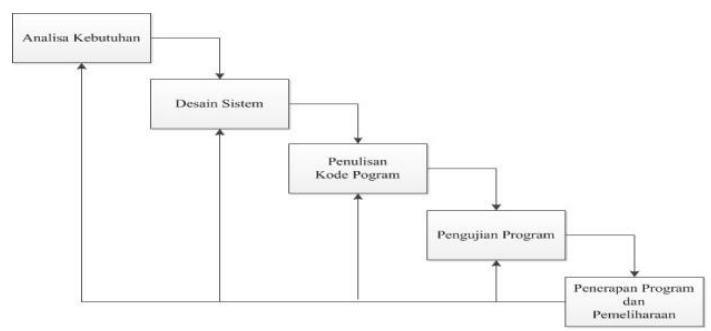

Gambar 1. Metode Waterfall

(Sumber: Kadir, 2003)
Tahapan Metode Waterfall (Kadir, 2003):

1. Analisa Kebutuhan

Langkah ini merupakan analisa terhadap kebutuhan sistem untuk membangun sistem informasi presensi fingerprint diktendik berbasis web. Pengumpulan data dalam tahap ini bisa melakukan sebuah penelitian, wawancara atau studi literatur.

2. Desain Sistem

Adalah tahapan menganalisa gambaran seperti apa sistem yang akan dibuat, bagaimana interface untuk setiap kegiatannya, serta mendefinisikan arsitektur sistem secara keseluruhan dari analisis membangun sistem informasi presensi fingerprint diktendik berbasis web.

3. Penulisan Kode Program

Penulisan kode program atau coding merupakan penerjemahan design dalam bahasa yang bisa dikenali oleh komputer. Dilakukan oleh programmer yang akan menterjemahkan transaksi yang diminta oleh user. Pada penelitian ini, penulisan kode program dilakukan menggunakan bahasa pemograman PHP dan database MySQL.

4. Pengujian Program

Tahapan akhir dimana sistem yang baru diuji kemampuan dan keefektifannya sehingga didapatkan kekurangan dan kelemahan sistem yang kemudian dilakukan pengkajian ulang dan perbaikan terhadap aplikasi menjadi lebih baik dan sempurna.

5. Penerapan Program dan Pemeliharaan

Penerapan sistem informasi presensi fingerprint diktendik berbasis web diterapkan di MA ArRosyidiyah Bengkalis dan dilakukan pemeliharaan.

\section{Hasil dan Pembahasan}

Sistem Informasi Presensi Fingerprint Diktendik Berbasis Web ini merupakan aplikasi pengeloaan presensi diktendik yang terintegrasi dengan mesin fingerprint di Madrasah Aliyah ArRosyidiyah Bengkalis yang dapat di pantau oleh Staf TU, kepala sekolah dan diktendik. Pada sistem ini untuk melakukan proses presensi pada mesin fingerprint, staf TU akan mendafarkan ID diktendik pada aplikasi, kemudian melakukan scan sidik jari pada mesin untuk merekam dan memverifikasi sidik jari setiap diktendik. Data hasil presensi akan diolah oleh aplikasi sistem presensi berbasis web menjadi rekap presensi dan grafik kehadiran.

Data hasil olahan presensi dapat dilihat oleh staf TU, kepala sekolah, dan diktendik dengan menu aplikasi presensi yang berbeda. Staf TU memberikan akses login kepada diktendik dan kepala sekolah untuk masuk ke aplikasi presensi berupa username dan password. Setelah masuk ke aplikasi, diktendik hanya dapat mengakses menu presensi sesuai dengan ID nya masing masing dan melihat hasil laporan presensi sesuai dengan ID nya sendiri. Untuk kepala sekolah, kepala sekolah hanya dapat melihat presensi diktendik dan grafik kehadiran diktendik. 


\subsection{Hasil}

a. Tampilan Halaman Login

Tampilan halaman login pada web untuk admin diisi berupa username dan password.

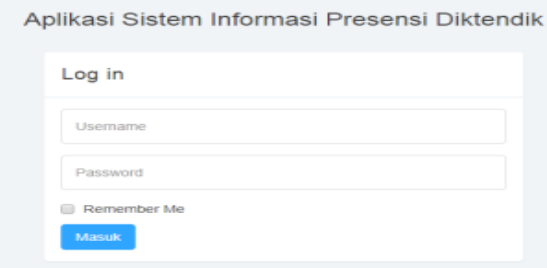

Gambar 2. Halaman Login

(Sumber: Data Olahan)

b. Tampilan Halaman Utama

Tampilan halaman utama pada aplikasi berisi menu menu yang ada pada pada aplikasi.

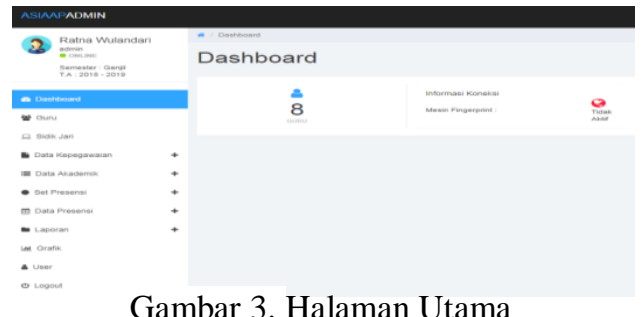

Gambar 3. Halaman Utama

(Sumber: Data Olahan)

c. Tampilan Halaman Guru

Tampilan halaman guru menampilkan data diktendik pada Madrasah Aliyah Arrosyidiyah Bengkalis.

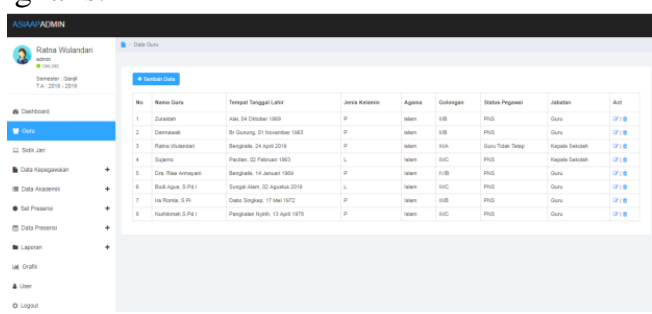

Gambar 4. Halaman Guru

(Sumber: Data Olahan)

d. Tampilan Halaman Sidik Jari

Tampilan halaman sidik jari mengelola data sidik jari diktendik oleh admin.

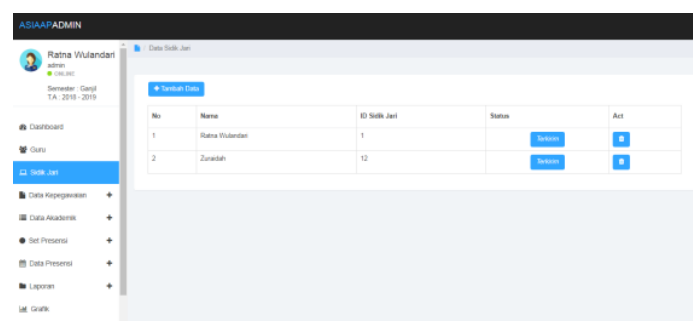

Gambar 5. Halaman Sidik Jari

(Sumber: Data Olahan) e. Tampilan Halaman Set Mesin

Tampilan halaman set meisn merupakan halaman untuk mengatur IP mesin fingerprint oleh admin.

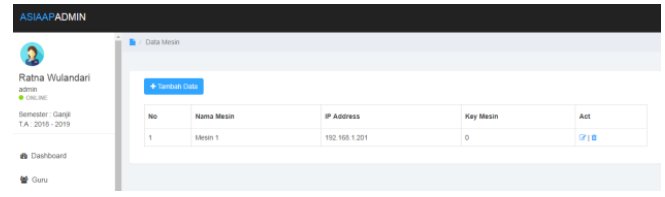

Gambar 6. Halaman Set Mesin

(Sumber: Data Olahan)

f. Tampilan Halaman Set Jadwal

Tampilan halaman set jadwal merupakan halaman untuk mengatur jadwal presensi oleh admin.

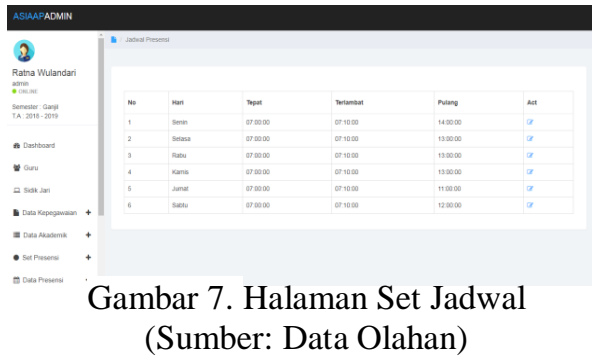

g. Tampilan Halaman Sinkron Data

Tampilan halaman sinkron merupakan halaman untuk sikronisasi data presensi yang ada pada mesin dan aplikasi.

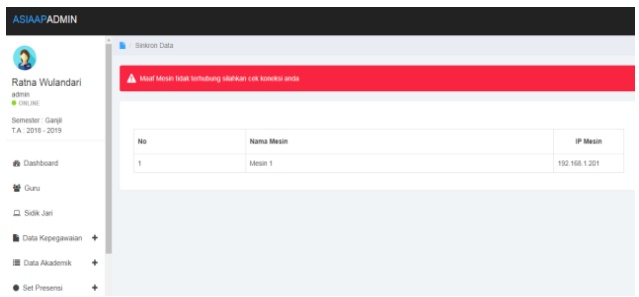

Gambar 8. Halaman Sinkron Data

(Sumber: Data Olahan)

h. Tampilan Halaman Presensi

Tampilan halaman merupakan halaman untuk menampilkan data presensi

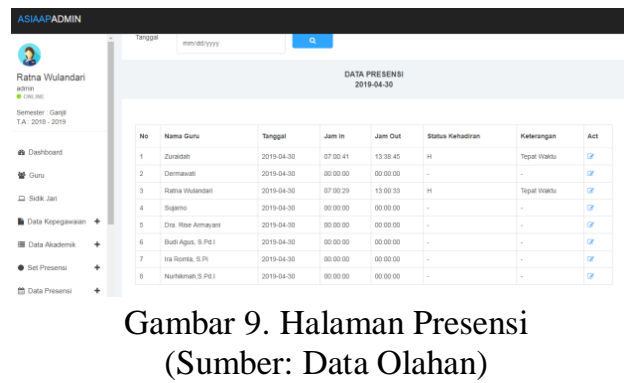

i. Tampilan Halaman Laporan Presensi

Tampilan halaman laporan merupakan halaman untuk menampilkan laporan bulanan presensi. 


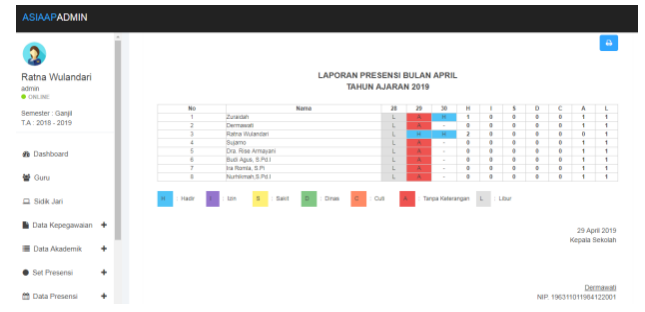

Gambar 10. Halaman Laporan Presensi (Sumber: Data Olahan)

j. Tampilan Halaman Laporan Data Guru

Tampilan halaman laporan data guru merupakan halaman untuk menampilkan laporan data guru.

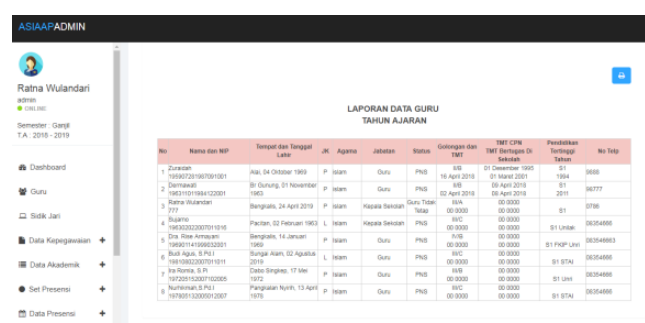

Gambar 11. Halaman Laporan Data Guru (Sumber: Data Olahan)

k. Tampilan Halaman Grafik

Tampilan halaman grafik merupakan halaman untuk menampilkan grafik kehadiran diktendik.

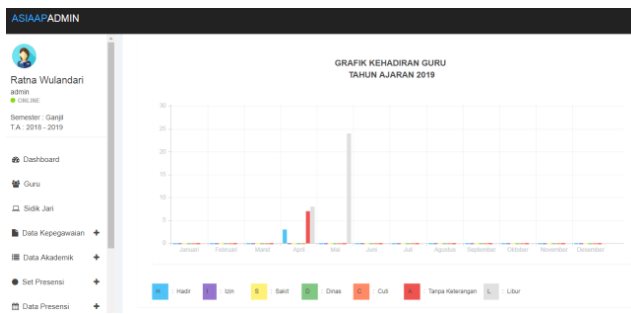

Gambar 12. Halaman Grafik

(Sumber: Data Olahan)

1. Tampilan Halaman User

Tampilan halaman user yang telah dibuat terlihat pada Gambar 5.19 merupakan tampilan data user yang dapat mengakses aplikasi.

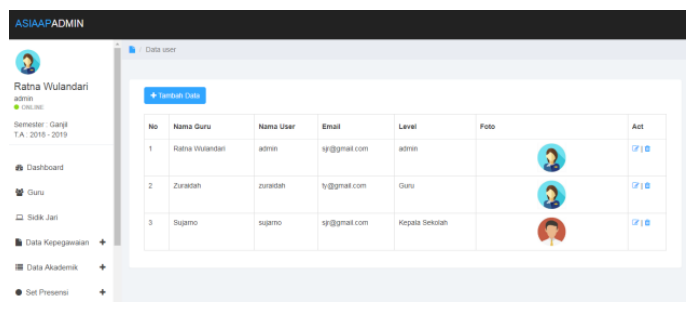

Gambar 13. Halaman User (Sumber: Data Olahan)

\subsection{Pengujian}

1) Pengujian Proses

Pengujian proses adalah pengujian yang dilakukan untuk mengetahui tingkat keberhasilan dari semua proses proses yang terjadi atau yang dapat dilakukan sistem yang telah dibangun, meliputi input dan output.

a. Pengujian Proses Admin

Pengujian proses admin merupakan semua proses-proses yang dapat dilakukan pada sisi administrator.

Tabel 1. Pengujian Proses Admin

\begin{tabular}{|c|c|c|c|}
\hline \multirow{2}{*}{ No } & \multirow{2}{*}{$\begin{array}{c}\text { Item Pengujian } \\
\text { Input/Output }\end{array}$} & \multicolumn{2}{|c|}{ Hasil } \\
\hline & & Berhasil & Gagal \\
\hline 1 & Login admin & $\checkmark$ & - \\
\hline 2 & $\begin{array}{l}\text { Menambah dan } \\
\text { mengelola akun baru } \\
\text { untuk user }\end{array}$ & $\checkmark$ & - \\
\hline 3 & $\begin{array}{l}\text { Menambah dan } \\
\text { mengelola data guru }\end{array}$ & $\checkmark$ & - \\
\hline 4 & $\begin{array}{l}\text { Menambah dan } \\
\text { mengelola data sidik } \\
\text { jari }\end{array}$ & $\checkmark$ & - \\
\hline 5 & $\begin{array}{lr}\text { Menambah dan } \\
\text { mengelola } \\
\text { kepegawaian }\end{array}$ & $\checkmark$ & - \\
\hline 6 & $\begin{array}{lr}\text { Menambah dan } \\
\text { mengelola } \\
\text { akademik }\end{array}$ & $\checkmark$ & - \\
\hline 7 & $\begin{array}{lr}\text { Menambah dan } \\
\text { mengelola } \\
\text { mesin }\end{array}$ & $\checkmark$ & - \\
\hline 8 & $\begin{array}{lr}\text { Menambah dan } \\
\text { mengelola } \\
\text { jadwal }\end{array}$ & $\checkmark$ & - \\
\hline 9 & $\begin{array}{lr}\begin{array}{l}\text { Menambah dan } \\
\text { mengelola } \\
\text { presensi }\end{array} & \text { data } \\
\end{array}$ & $\checkmark$ & - \\
\hline 10 & $\begin{array}{l}\text { Sinkron data mesin } \\
\text { dan aplikasi }\end{array}$ & $\checkmark$ & - \\
\hline 11 & $\begin{array}{lr}\text { Menambah dan } \\
\text { mengelola } \\
\text { ketidakhadiran }\end{array}$ & $\checkmark$ & - \\
\hline 7 & $\begin{array}{l}\text { Melihat laporan } \\
\text { bulanan presensi }\end{array}$ & $\checkmark$ & - \\
\hline 8 & $\begin{array}{l}\text { Melihat laporan data } \\
\text { guru }\end{array}$ & $\checkmark$ & - \\
\hline 10 & $\begin{array}{ll}\text { Melihat } & \text { grafik } \\
\text { kehadiran } & \end{array}$ & $\checkmark$ & - \\
\hline
\end{tabular}

(Sumber: Data olahan) 
b. Pengujian Proses User

Pengujian proses admin merupakan semua proses-proses yang dapat dilakukan pada sisi user yaitu, diktendik dan Kepala Sekolah. Adapun prosesproses yang dapat dilakukan pada sisi user dapat dilihat seperti pada Tabel 2 .

Tabel 2. Pengujian Proses User

\begin{tabular}{|c|c|c|c|}
\hline \multirow{2}{*}{ No } & \multirow{2}{*}{$\begin{array}{c}\text { Item Pengujian } \\
\text { Input/Output }\end{array}$} & \multicolumn{2}{|c|}{ Hasil } \\
\hline & & Berhasil & Gagal \\
\hline 1 & \multicolumn{3}{|c|}{ Diktendik } \\
\hline & -Login aplikasi & $\checkmark$ & - \\
\hline & $\begin{array}{l}\text { - Melihat data presensi } \\
\text { diktendik sesuai ID }\end{array}$ & $\checkmark$ & - \\
\hline & $\begin{array}{l}\text { - Melihat data laporan } \\
\text { bulanan sesuai ID }\end{array}$ & $\checkmark$ & - \\
\hline 2 & \multicolumn{3}{|l|}{ Kepala Sekolah } \\
\hline & -Login aplikasi & $\checkmark$ & - \\
\hline & $\begin{array}{l}\text { - Melihat data dan } \\
\text { laporan presensi } \\
\text { diktendik }\end{array}$ & $\checkmark$ & - \\
\hline & $\begin{array}{l}\text { - Melihat grafik } \\
\text { diktendik }\end{array}$ & $\checkmark$ & - \\
\hline
\end{tabular}

(Sumber: Data olahan)

c. Pengujian Proses Kirim Terima Data

Pengujian proses kirim terima data merupakan semua proses-proses kirim terima data yang dilakukan oleh aplikasi presensi terhadap mesin fingerprint. Adapun proses-proses yang dapat dilakukan oleh aplikasi presensi dapat dilihat seperti pada Tabel 3.

Tabel 3. Pengujian Proses Kirim Terima Data

\begin{tabular}{|c|l|c|c|}
\hline \multirow{2}{*}{ No } & \multirow{2}{*}{ Item Pengujian } & \multicolumn{2}{|c|}{ Hasil } \\
\cline { 2 - 4 } 1 & $\begin{array}{l}\text { Sinkron data ID } \\
\text { diktendik }\end{array}$ & $\checkmark$ & Gerhasil \\
\hline 2 & $\begin{array}{l}\text { Sinkron data } \\
\text { presensi }\end{array}$ & $\checkmark$ & - \\
\hline
\end{tabular}

(Sumber : Data Olahan)

\section{d. Pengujian pada Webbrowser}

Pengujian aplikasi pada webbrowser dilakukan pada beberapa webbrowser yaitu Google Chrome dan Mozilla Firefox. Pengujian dilakukan untuk mengetahui keberhasilan program. Pengujian pada webbrowser dapat dilihat seperti pada Tabel 4.

Tabel 4. Pengujian pada Webbrowser

\begin{tabular}{|c|l|c|c|}
\hline \multirow{2}{*}{ No } & \multirow{2}{*}{ Item Pengujian } & \multicolumn{2}{|c|}{ Hasil } \\
\cline { 3 - 4 } & & Berhasil & Gagal \\
\hline 1 & Google Chrome & $\checkmark$ & - \\
\hline 2 & Mozilla Firefox & $\checkmark$ & - \\
\hline
\end{tabular}

(Sumber: Data Olahan)

\section{Kesimpulan dan Saran}

Berdasarkan hasil analisis dan pembahasan serta uraian dari bab-bab sebelumnya maka dapat disimpulkan :

1. Sistem informasi presensi fingerprint diktendik berbasis web, mampu mengubah kegiatan presensi yang menggunakan cara manual menjadi menggunakan sistem yang terintegrasi dengan fingerprint.

2. Sistem informasi presensi fingerprint diktendik berbasis web, mampu mempermudah staf tata usaha dalam hal mencari dan mengolah data presensi.

3. Sistem informasi presensi fingerprint diktendik berbasis web, mampu meningkatkan keamanan presensi.

Berdasarkan kesimpulan dari penelitian ini, maka peneliti memberikan beberapa saran yang dapat dijadikan acuan untuk mengembangkan sistem informasi presensi diktendik berbasis web adapun saran peneliti adalah sebagai berikut:

1. Pada penelitian ini, menggunakan asumsi penggunaan prosedur standar presensi sehingga perlu penyesuaian lagi jika mempunyai kondisi lain selanin presensi masuk dan keluar.

2. Sistem dapat dikembangkan dengan adanya fitur notifikasi jadwal mengajar bagi diktendik.

3. Pemeliharaan terhadap aplikasi dilakukan secara berkala agar aplikasi dapat digunakan dalam jangka waktu yang lama.

\section{Daftar Pustaka :}

Dewi, M., Anggraeni, V.D., Mudjadi, S.A., dan Wicaksono, A., (2014) Aplikasi Rekapitulasi Elektronik Absensi Guru \& Pegawai (Area-Gp) Pada Sekolah Menengah Atas, Seminar Nasional Teknologi Informasi dan Komunikasi 2014 (SENTIKA 2014).

Dewi, Rodhiyana., Hasanah, P., dan Rohmatulloh., (2015) Perancangan dan Implementasi Sistem Presensi Berbasis Finger Print di SMPN 1 Tanjunganom, e-Proceeding of Applied Science , (2), 1, 2442-5826.

Efendi, U., (2014) Sistem Presensi Online Berbasis Web Service dengan Integerasi antara sistem sidik jari dan login e-learning, Program Studi Sistem Informasi Universitas Jember, Jember.

Hidayat, A. N. (2015). Belajar HTML Kelas Ringkas. bisakimia.

Jamil, M., dan Bunyamin, (2015) Pengembangan Aplikasi Sistem Informasi Laporankeuangan Walisantri Di Pondok Pesanren, Jurnal Algoritma , (12), 1, 2302-7339.

Kadir, Abdul. (2014). Pengenalan Sistem Informasi. Andi. Yogyakarta.

Komputer, Wahana. (2009). PHP Programing. Andi Offset. Yogyakarta. 
Palit, R.V., Rindengan, Y.D.Y., Lumentas, A.S.M., (2015) Rancangan Sistem Informasi Keuangan Gereja Berbasis Web Di Jemaat GMIM Bukit Moria Malalayang, E-Journal Teknik Elektro dan Komputer, (4), 7, 2301-8402.

Pai, A., V., Krishna, A., Kshama., Corres, M., (2016) Web Services for student attendance management system, International Journal of Advance Research in Science and engineering, (5),3.

Rozaq, A., Lestari, K.F., Handayani, S., (2015). Sistem Informasi Produk Dan Data Calon Jamaah Haji Dan Umroh Pada Pt. Travellindo Lusiyana Banjarmasin Berbasis Web,Jurnal POSITIF , (1), 1, 1-13.

Rozikin, K., Purwantini, K., (2014). Pengaruh Sistem Presensi dengan Deteksi Sidik Jari dan SMS Gateway Terhadap Tingkat Membolos Siswa, Seminar Nasional Teknologi Informasi \& Komunikasi Terapan 2014(Semantik 2014).

Septiawan, D., Kridalukmana, R., Windasari, I., P., (2016) Perancangan dan Implementasi Presensi Digital Guru dan Karyawan SMA Negeri 9 Semarang, Jurnal Teknologi dan Sistem Komputer, (2), 4.

Shalahuddin, M dan S, Rosa A. (2013). Rekayasa Perangkat Lunak Terstruktur dan Berorientasi Objek. Informatika. Bandung.

Sutabri, Tata. (2012). Analisa Sistem Informasi. Andi. Yogyakarta.

Tullah, R., \& Hanafri, M. I. (2014). Evaluasi Penerapan Sistem Informasi Pada Politeknik LP3I Jakarta Dengan Metode Pieces. Jurnal Sisfotek Global, 4(1).

Tim EMS. (2012). Web Programming For Beginners. PT.Alex Media Komputindo. Jakarta.

Wardani, S. K. (2013). Sistem Informasi Pengolahan Data Nilai Siswa Berbasis Web Pada Sekolah $\begin{array}{llll}\text { Menengah Kejuruan (SMK) PGRI } 1 & \end{array}$ Pacitan. EPUB-SISTEM INFORMASI, 1(1).

Yakub. (2012). Pengantar Sistem Informasi. Graha Ilmu. Yogyakarta. 